健康成人皮䖒毛細血管像二及又

$$
\begin{aligned}
& \text { あどれなんノ影響二就テ }
\end{aligned}
$$

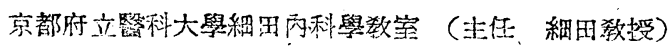

$$
\begin{aligned}
& \text { 研究科學生 㗨學士川本 盛, 四 郎 } \\
& \text { (昭和24华4.月5日涭附) }
\end{aligned}
$$

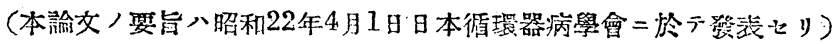

\title{
Influence of adrenalin on capillary of skin of adult healthy body.
}

By

\author{
Seishiro Kawamoto, M.D. \\ Interna! Medical Section, Kyoto Prefectural Medical College. \\ (Chief: Prof. Dr. Hosoda)
}

I investigated the form, the speed of Capillary stream, the changes of subpapillar venous plexus, and the pigmentation of the basilar part in Sulcus subungualis on left ring finger.

I measured the width and the lengh of Capillary by ocular Micrometer, Adrenalin was used locally as a solution of 1:2000 or 1:5000 Adrenalin Glycerin, and subcutaneously as $0.1 \mathrm{cc}$ of 1: $1000 \mathrm{HCl}$ - Adrenalin per kilo-gram body weight, The result was as follows.

By the treatment of adrenalin, venous and arterial capillaries of skin contracted, the speed of blood stream became slow and the pigmentation of basilar part became lighter. These changes were proportional to concentration of adrenalin, and were stronger in subcutaneous application than in local application.

The reaction of adrenalin was stronger in man than in woman.

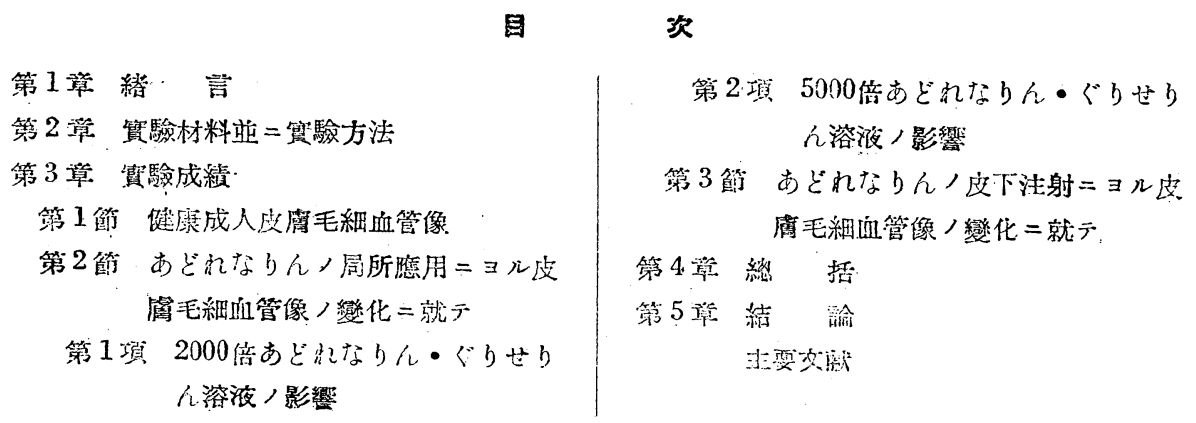

\section{第 1 音 緒}

票

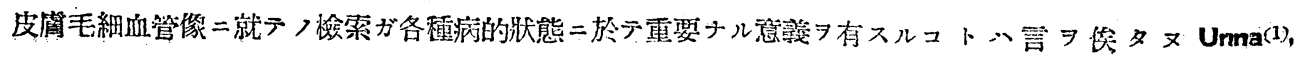




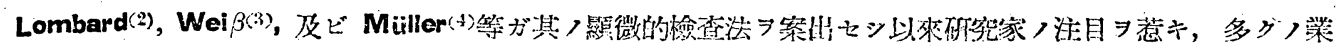
綪アレドモ未ダ残サレタル所モ办尠クナイ。

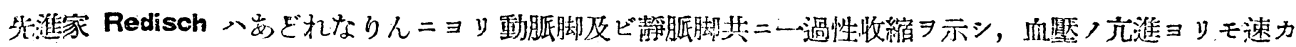

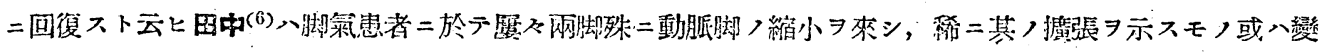

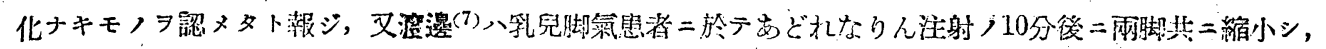
血流入稍々急速トナり 2 分後二復歸スト云フ.

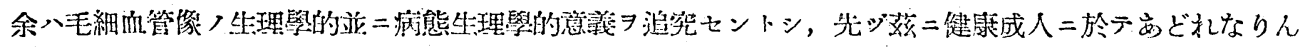

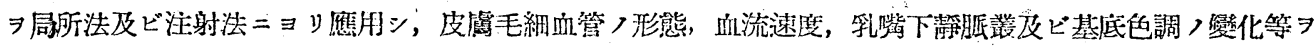
唯察シタ.

\section{第 2 醉 驗材料並に實騟方法}

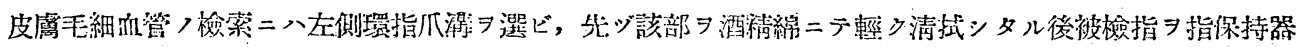

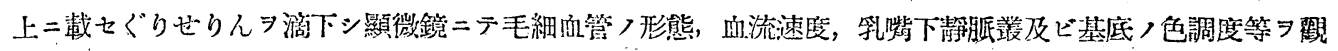
察シタ.

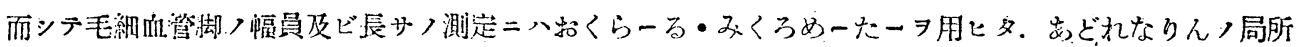

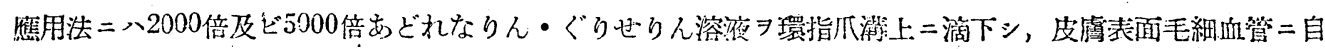

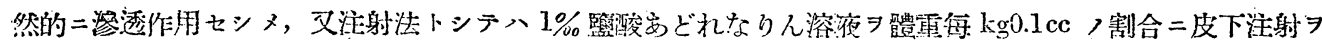
行ッタ.

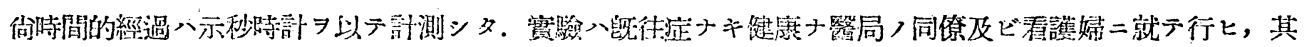

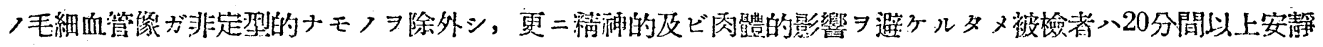

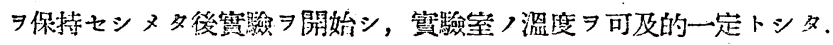

\section{第了章 䁇、驗 成 績

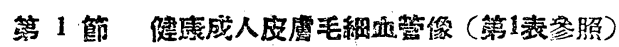

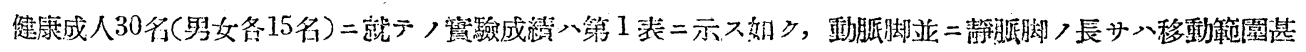

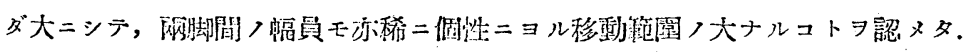

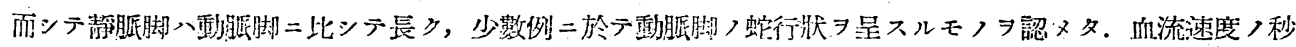

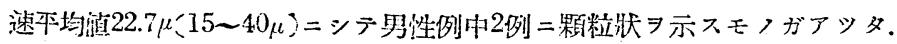

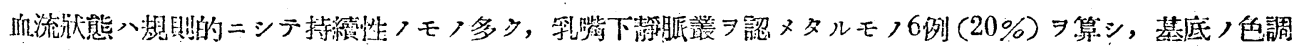

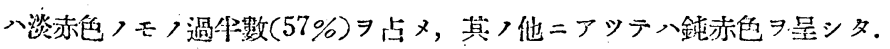

管 1 证庭成人皮激毛細血管像

\begin{tabular}{|c|c|c|c|c|c|c|c|c|c|c|c|c|c|}
\hline \multirow{3}{*}{ 侧 } & \multirow{3}{*}{$\begin{array}{l}\text { 年 } \\
\text { 龄 } \\
\end{array}$} & \multirow{3}{*}{$\begin{array}{l}\text { 性: } \\
\text { 别 }\end{array}$} & \multicolumn{3}{|c|}{ 形 } & \multicolumn{3}{|c|}{ 絧 } & \multicolumn{2}{|r|}{ 血 } & 1): & \multirow{3}{*}{ 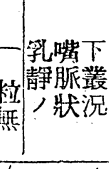 } & \multirow{3}{*}{ 基底 } \\
\hline & & & \multicolumn{2}{|c|}{ 靜 脈 䀷 } & \multicolumn{2}{|c|}{ 動 㟲 脚 } & \multirow{2}{*}{\multicolumn{2}{|c|}{${ }^{\prime}(\mu)$ 間蛇 }} & \multirow{2}{*}{$\begin{array}{l}\text { 行血 } \\
\text { 沙速 } \\
\text { 秒 } / 4\end{array}$} & \multirow{2}{*}{ 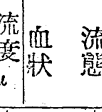 } & \multirow{2}{*}{ 荒顆 粒 } & & \\
\hline & & & $\begin{array}{l}\text { 幅 } \\
(\mu)\end{array}$ & $\begin{array}{l}\text { 長者 } \\
(\mu)\end{array}$ & $\begin{array}{l}\text { 幅 } \\
(\mu)\end{array}$ & $\begin{array}{l}\text { 長 } \\
(\mu)\end{array}$ & & & & & & & \\
\hline 1 & 35 & 令 & 10 & 210 & 7 & 100 & 20 & 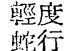 & 23 & 持續性 & $(-) \mid$ & $(-)$ & 鈍赤色 \\
\hline 2 & 27 & $\hat{\delta}$ & 10 & 220 & 8 & 110 & 15 & $(-)$ & 20 & $" \prime$ & $(-)$ & $(-)$ & $" 1$ \\
\hline 3 & 27 & $\hat{\delta}$ & 10 & 210 & 8 & 50 & 10 & $(-)$ & 25 & "I & $(-)$ & $(+)$ & "l \\
\hline 4 & 28 & 令 & 15 & 220 & 10 & 100 & 20 & $(-)$ & 25 & "I & $(-)$ & $(+)$ & 淡赤色 \\
\hline 5 & 26 & $\hat{\delta}$ & 10 & 160 & 7 & 30 & 10 & $(-)$ & 25 & $" 1$ & $(-)$ & $(-)$ & $\therefore$ \\
\hline 6 & 28 & $\hat{\delta}$ & 15 & 160 & 11 & 40 & 15 & $(-)$ & 20 & $\mid$ & $(-)$ & $(t)$ & $" 1$ \\
\hline 7 & 29 & $\hat{\delta}$ & 12 & 230 & 10 & 110 & 30 & $(-)$ & 19 & 特續性 & $(-)$ & $(t)$ & " \\
\hline 8 & 34 & $\hat{\delta}$ & 11 & 210 & 10 & 105 & 20 & $(-)$ & 24 & "I & $(-)$ & $(-)$ & 鈍赤色 \\
\hline
\end{tabular}




\begin{tabular}{|c|c|c|c|c|c|c|c|c|c|c|c|c|c|}
\hline 9 & 31. & $\hat{\delta}$ & 15 & 200 & 10 & 105 & 20 & $(-)$ & 19 & 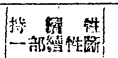 & 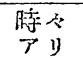 & $(-)$ & 淡赤任 \\
\hline 10 & 35 & $\hat{\sigma}$ & 12 & 260 & 10 & 110 & 15 & $(-)$ & 17 & 持續性 & $(-)$ & $(-)$ & $" 1$ \\
\hline il & 32 & $\hat{\delta}$ & 10 & 260 & 5 & 160 & 20 & $(-)$ & 19 & " & $(-)$ & $(-)$ & "I \\
\hline 12 & 35 & $\widehat{\delta}$ & 12 & 260 & 10 & 160. & 25 & $(-)$ & 20 & 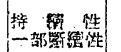 & 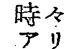 & $(t)$ & ." \\
\hline 13 & 26 & $\hat{\delta}$ & 10 & 150 & 10 & 100 & 12 & $(-)$ & 15 & "I & $(-)$ & $(-)$ & 鈍赤色 \\
\hline 14 & 25 & $\hat{\delta}$ & 12 & 210 & 8 & 70 & 15 & $(-)$ & 33 & " & $(-)$ & $(-)$ & !" \\
\hline 15 & 25 & $\widehat{s}$ & 12 & 100 & 6 & 109 & 11 & & 22 & $"$ & $(-)$ & $(+)$ & 淡浾画 \\
\hline 16 & 25 & 우 & 15 & 170 & 8 & 90 & 15 & $(-)$ & 15 & " & $(-)$ & $(-)$ & " \\
\hline 17 & 23 & 우 & 15 & 210 & 13 & 150 & 10 & $(-)$ & 33 & "I & $(-)$ & $(-)$ & " \\
\hline 18 & 23 & 우 & 10 & 270 & 8 & 220 & 8 & $(-)$ & 28 & 持續性 & $(-)$ & $(-)$ & 滺赤色 \\
\hline 19 & 24 & 우 & 10 & 220 & 10 & 100 & 15 & $(-)$ & 40 & " & $(-)$ & $(-)$ & "I \\
\hline 20 & 23 & 오 & 10 & 170 & 10 & 150 & 15 & $(-)$ & 28 & if & $(-)$ & $(-)$ & 釱赤色 \\
\hline 21 & 25 & 우 & 17 & 260 & 15 & 160 & 17 & $(-)$ & $20^{\circ}$ & "I & $(-)$ & $(-) \mid$ & " \\
\hline 22 & 22 & 우 & 10 & 180 & 10 & 90 & 13 & $(-)$ & 18 & " & $(-)$ & $(-)$ & " \\
\hline 23 & 17 & 우 & 11 & 200 & 10 & 90 & 10 & $(-)$ & 18 & " & $(-)$ & $(-)$ & " \\
\hline 24 & 21 & 우 & 15 & 200 & 10 & 140 & 15 & $(-)$ & 19 & " & $(\cdots)$ & $(-)$ & 淡赤色 \\
\hline 25 & 19 & 우 & 15 & 150 & 15 & 100 & 10 & $(-)$ & 18 & "I & $(-)$ & $(-)$ & 釛赤色 \\
\hline 26 & 19 & 우 & 10 & 210 & 9 & 90 & 10 & $(-)$ & 25 . & "I & $(-)$ & $(-)$ & "I \\
\hline 27 & 23 & 오 & 15 & 160 & 15 & 150 & 10 & $(-)$ & 33 & !" & $(-)$ & $(-)$ & 滺赤色 \\
\hline 28 & 18 & 우 & 10 & 233 & 10 & 180 & 10 & $(-)$ & 25 & " & $(-)$ & $(-)$ & "I \\
\hline 29 & 17 & 우 & 10 & 190 & 10 & 90 & 13 & $(-)$ & 18 & "I & $(-)$ & $(-)$ & 鈍赤色 \\
\hline 30 & $2 \mathrm{~L}$ & 우 & 10 & 210 & 10 & 100 & 15 & $(-)$ & 20 & "! & $(-)$ & $(-)$ & 濙赤色 \\
\hline 男 & 子 平 & 均 & 11.6 & 204 & 8.7 & 96.7 & 17.2 & & 21.7 & & & & \\
\hline 女 & 子 平 & 均 & 12.2 & 202 & 10.9 & 126.7 & 12.4 & & 23.9 & & & & \\
\hline 總 & 푸 & 均 & 11.9 & 205.3 & 9.8 & 111.6 & 14.8 & & 22.7 & & & & \\
\hline
\end{tabular}

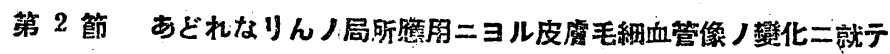

\section{新 1 . 項 2000倍あどれなりん・ぐりせりん溶液ノ影響 (第2表參照)}

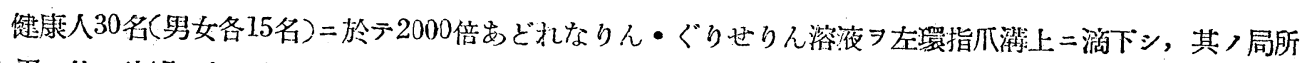

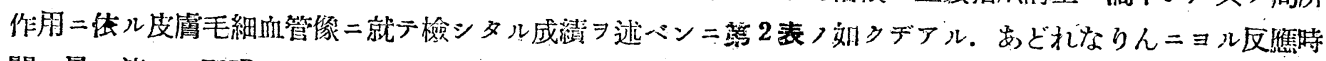

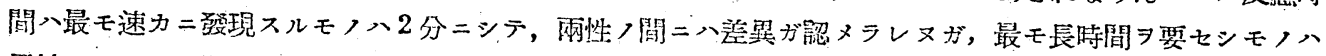

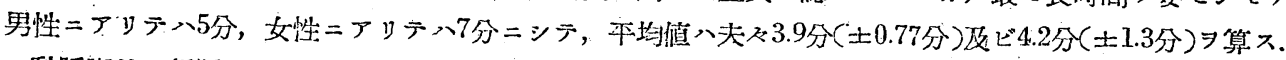

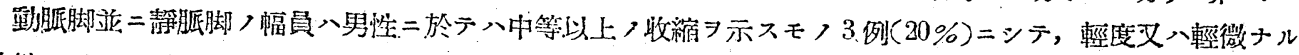

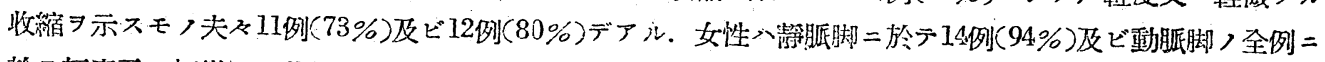
於テ輕度刃八輕微ナル收縮ヨ示シタ。

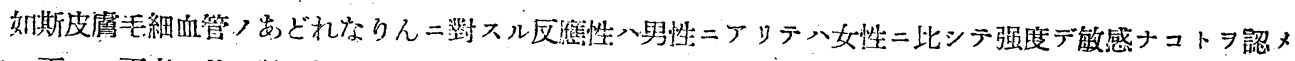

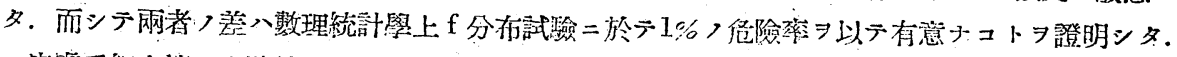

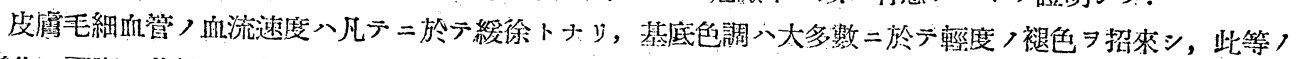
變化八兩脚ノ收縮卜密接ナ關連习有ツコトラ認メダ。

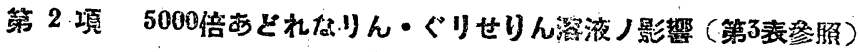

今毛細血管像ノ變化 $习$ 述ベン二㶾 3 表二示ス如クデアル。

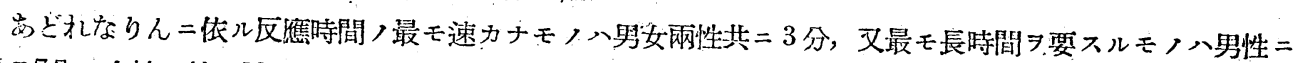

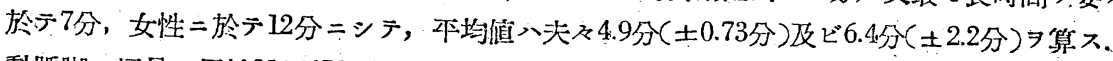

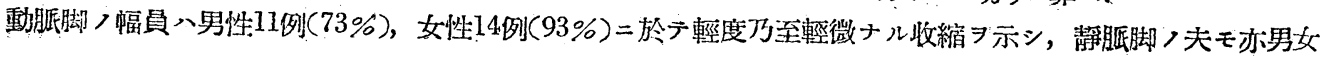




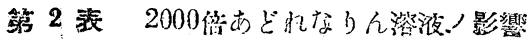

\begin{tabular}{|c|c|c|c|c|c|c|c|c|c|c|}
\hline \multirow{3}{*}{$\begin{array}{l}\text { 例 } \\
\text { 數 }\end{array}$} & \multirow{3}{*}{$\begin{array}{l}\text { 年 } \\
\text { 龄 }\end{array}$} & \multirow{3}{*}{$\begin{array}{l}\text { 筌 } \\
\text { 别 }\end{array}$} & \multirow{3}{*}{$\begin{array}{l}\text { 酦 } \\
\text { 業 }\end{array}$} & \multirow{3}{*}{ 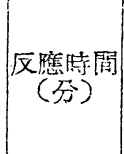 } & & 反 & 辟 & 狀 & \multicolumn{2}{|l|}{ 熊 } \\
\hline & & & & & \multicolumn{2}{|c|}{ 幅員ノ縮小 } & \multicolumn{2}{|c|}{ 血流涑度 } & \multirow{2}{*}{ 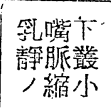 } & \multirow{2}{*}{ 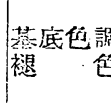 } \\
\hline & & & & & 静脈脚 & 重脈脚 & 縰 笨 & 促 進 & & \\
\hline 1 & 35 & $\hat{\delta}$ & 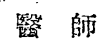 & 3 & $(H+1)$ & $(H)$ & $(H)$ & \multirow{30}{*}{ 始 } & $(-)$ & $(+)$ \\
\hline 2 & 27 & 杏 & $" 1$ & 3 & $(+)$ & $(+t)$ & $(+)$ & & $(-)$ & $(+)$ \\
\hline 3 & 27 & $\hat{\delta}$ & "l & 4 & $(+)$ & $(t)$ & $(+)$ & & $(t)$ & $(+)$ \\
\hline 4 & 28 & $\hat{\delta}$ & " & $4_{i}$ & $(+)$ & $(+)$ & $(+)$ & & $(-)$ & (t) \\
\hline 5 & 26 & 今 & " & 3.5 & $( \pm)$ & $(t)$ & (土) & & $(-)$ & $( \pm)$ \\
\hline 6 & 28 & $\hat{\sigma}$ & "I & 5 & $(+)$ & $(t)$ & $(t)$ & & $(-)$ & (士) \\
\hline 7 & 29 & $\hat{\sigma}$ & "l & 3 & $( \pm)$ & $(+)$ & $(+)$ & & $(-)$ & $( \pm)$ \\
\hline 8 & 34 & $\hat{\sigma}$ & " & 4.5 & $(+)$ & $(t)$ & $(+)$ & & $(-)$ & $( \pm)$ \\
\hline 9 & 31 & $\hat{\circ}$ & "l & 4.1 & $( \pm)$ & $( \pm)$ & $(+)$ & & $(-)$ & $( \pm)$ \\
\hline 10 & 25 & $\hat{\sigma}$ & "ll & 5 & $3+1$ & $(-)$ & $(+2)$ & & $(-)$ & $( \pm)$ \\
\hline 11 & 32 & $\hat{\delta}$ & " & 3 & $( \pm)$ & $(t)$ & $(+)$ & & $(-)$ & $(+)$ \\
\hline 12 & 35 & $\hat{\delta}$ & " & 2 & (Hi) & $(\mathrm{HH})$ & $(+t)$ & & $(+1)$ & (H) \\
\hline 13 & 26 & $\widehat{\hat{\delta}}$ & 醫學生 & 5 & $(t+)$ & $(+)$ & $(+)$ & & $(-)$ & $( \pm)$ \\
\hline 14 & 25 & $\hat{\delta}$ & 11 & 4.5 & $(t)$ & $(+)^{\prime}$ & $(+)$ & & $(-)$ & $(+)$ \\
\hline 15 & 25 & $\widehat{\hat{\delta}}$ & "I & 5 & $(+t)$ & $(+)$ & $(+)$ & & $(+)$ & $(+)$ \\
\hline 16 & 25 & 우 & 女，醫 & $?$ & $(t)$ & $(+)$ & $(+)$ & & $(\therefore)$ & -+1 \\
\hline 17 & 23 & 우 & $"$ & 4 & $( \pm)$ & $( \pm)$ & $(+)$ & & $(-)$ & (亡) \\
\hline 18 & 23 & 우 & " & 2.5 & $(+)$ & $( \pm)$ & $(+)$ & & $(-)$ & $(+)$ \\
\hline 19 & 24 & 우 & "I & 2 & $(+)$ & $( \pm)$ & $(+)$ & & $(-)$ & $(+)$ \\
\hline 20 & 23 & 우 & $" \prime$ & 3 & $( \pm)$ & $(+)$ & $( \pm)$ & & $(-)$ & $( \pm)$ \\
\hline 21 & 25 & 우 & 雷護婦 & 3.5 & $(+)$ & $(+)$ & $( \pm)$ & & $(-)$ & (土) \\
\hline 22 & 22 & 우 & "I & 7 & (土) & $( \pm)$ & (士) & & $(-)$ & $(+)$ \\
\hline 23 & 17 & 우 & "l & 5.5 & $( \pm)$ & $( \pm)$ & $(t)$ & & $(-)$ & $(+)$ \\
\hline 24 & 21 & 우 & $" 1$ & 4 & $(-)$ & $( \pm)$ & $(+)$ & & $(-)$ & $(-)$ \\
\hline 25 & 19 & 우 & "l & 3 & $(+)$ & $(+)$ & $(+)$ & & $(-)$ & $(t)$ \\
\hline 26 & 19 & 오 & $" \prime$ & 3 & $( \pm)$ & $(t)$ & $(+)$ & & $(-)$ & $(+)$ \\
\hline 27 & 23 & 우 & $"$ & 3 & $(+)$ & $( \pm)$ & $(+)$ & & $(-)$ & $(+)$ \\
\hline 28 & 18 & 우 & "I & 5.5 & $(+)$ & (土) & $(+)$ & & $(-)$ & $(+)$ \\
\hline 29 & 17 & 오 & $"$ & 3 & (I) & $( \pm)$ & $(+)$ & & $(-)$ & $(+)$ \\
\hline 30 & 21 & 우 & " & 7 & $( \pm)$ & $( \pm)$ & (土) & & $(-)$ & $(+)$ \\
\hline \multicolumn{3}{|c|}{ 男于本均 } & & 3.9 & (Hi) 全 2 & $\begin{array}{l}2 \\
0 \\
\end{array}$ & $\begin{array}{l}0 \\
0\end{array}$ & & $\begin{array}{l}0 \\
0\end{array}$ & $\begin{array}{l}0 \\
0\end{array}$ \\
\hline \multicolumn{3}{|c|}{ 文于梨均 } & & 4.2 & (it) $\begin{array}{l}\text { 令1 } \\
\text { + } 0\end{array}$ & $\begin{array}{l}1 \\
0\end{array}$ & $\begin{array}{l}2 \\
0\end{array}$ & & $\begin{array}{l}1 \\
0\end{array}$ & $\begin{array}{l}1 \\
0\end{array}$ \\
\hline \multirow[t]{3}{*}{ 新忽 } & $\pi$ & 昜 & & 4.1 & $\therefore+\begin{array}{r}18 \\
+7\end{array}$ & $\begin{array}{r}10 \\
5 \\
\end{array}$ & $\begin{array}{l}10 \\
11\end{array}$ & & $\begin{array}{l}2 \\
0\end{array}$ & $\begin{array}{r}6 \\
11\end{array}$ \\
\hline & & & & & $( \pm) \begin{array}{l}\hat{\delta} 4 \\
+7\end{array}$ & $\begin{array}{r}1 \\
10 \\
\end{array}$ & $\begin{array}{l}2 \\
4 \\
\end{array}$ & & $\begin{array}{l}0 \\
0\end{array}$ & $\begin{array}{l}8 \\
4 \\
\end{array}$ \\
\hline & & & & & $(-) \begin{array}{l}\hat{0} 0 \\
+ \\
\end{array}$ & $\begin{array}{l}1 \\
0 \\
\end{array}$ & $\begin{array}{l}1 \\
0 \\
-0\end{array}$ & & $\begin{array}{l}12 \\
15\end{array}$ & $\begin{array}{l}0 \\
0\end{array}$ \\
\hline
\end{tabular}

各14例 $(93 \%)=$ 於テ前者卜同樣ノ所見 7 招來シタ.

而シテ雨者，間二八数理統計學上 $\mathrm{f}$ 分布試驗二於テ有意ナ差異分存在セナイ.

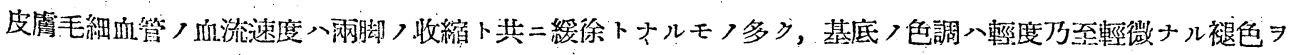

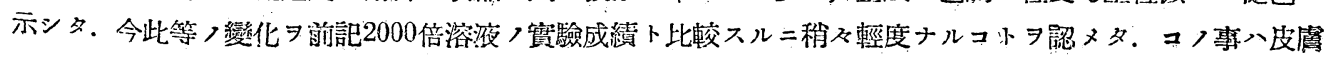




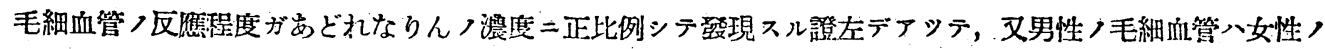
夫レョリモあどれなりんニ對シ敏感ナルコトヨ認ムざキ結果二到達シタ。

筇 る表 5000 倍あどれなりん溶液ノ影響

\begin{tabular}{|c|c|c|c|c|c|c|c|c|c|c|}
\hline \multirow{3}{*}{$\begin{array}{l}\text { 例 } \\
\text { 數 }\end{array}$} & \multirow{3}{*}{$\begin{array}{l}\text { 年 } \\
\text { 齢 }\end{array}$} & \multirow{3}{*}{$\begin{array}{l}\text { 性 } \\
\text { 別 }\end{array}$} & \multirow{3}{*}{$\begin{array}{l}\text { 䇿 } \\
\text { 業 }\end{array}$} & \multirow{3}{*}{\begin{tabular}{|} 
反監時間 \\
(分)
\end{tabular}} & & 区 & 憑 & 狀 & \multicolumn{2}{|l|}{ 䜿 } \\
\hline & & & & & \multicolumn{2}{|c|}{ 幅員”繀小 } & \multicolumn{2}{|c|}{ 血流速度 } & \multirow{2}{*}{ 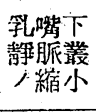 } & \multirow{2}{*}{ 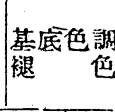 } \\
\hline & & & & & 靜脈㑢 & 動朖脚 & 綬 徐 & 促 萑 & & \\
\hline 1 & 35 & ๙ิ & 醫 師 & 4 & $( \pm)$ & $(+)$ & & & $(-)$ & $( \pm)$ \\
\hline 2 & 27 & $\hat{\delta}$ & " & 4 & $( \pm)$ & $( \pm)$ & & & $(-)$ & (土) \\
\hline 3 & 27 & $\hat{\delta}$ & " & 5 & (I) & \pm & & & $( \pm)$ & $( \pm)$ \\
\hline 4 & 23 & $\hat{o}$ & " & 6 & $(+)$ & $(+)$ & & & $(-)$ & $( \pm)$ \\
\hline 5 & 26 & $\widehat{o}$ & " & 5 & $(-)$ & $( \pm)$ & & & $(-)$ & (士) \\
\hline 6 & 28 & $\hat{\delta}$ & " & 7 & $( \pm)$ & $(-)$ & & & $(-)$ & ( \pm$)$ \\
\hline 7 & 29 & $\hat{\delta}$ & " & 5 & $( \pm)$ & $(+)$ & & & $(-)$ & $( \pm)$ \\
\hline 8 & 34 & $\hat{\sigma}$ & " & 7 & $(+)$ & $( \pm)$ & & & $(-)$ & (士) \\
\hline 9 & 31 & $\hat{\delta}$ & " & 7 & $( \pm)$ & $(-)$ & & & $(-)$ & $( \pm)$ \\
\hline 10 & 35 & $\hat{\delta}$ & "I & 4 & $( \pm)$ & $(-)$ & & & $(-)$ & $(+)$ \\
\hline 11 & 32 & $\hat{\delta}$ & " & 3 & $( \pm)$ & $( \pm)$ & & & $(-)$ & $( \pm)$ \\
\hline 12 & 35 & $\hat{\delta}$ & " & 4 & (士t) & $(+)$ & & & $(+)$ & $(+)$ \\
\hline 13 & 26 & $\hat{\delta}$ & 䈉學生 & 3 & $( \pm)$ & (I) & & & $(-)$ & $( \pm)$ \\
\hline 14 & 25 & $\hat{\delta}$ & " & 4 & $( \pm)$ & $(-)$ & & & $(-)$ & $(-)$ \\
\hline 15 & 25 & $\hat{\delta}$ & " & 5 & $( \pm)$ & $(+)$ & & & ( \pm 2 & (土) \\
\hline 16 & 25 & 우 & 女 醫 & 7.5 & $(+)$ & $( \pm)$ & & & $(-)$ & $(+)$ \\
\hline 17 & 23 & 우 & $"$ & 4.5 & $(-)$ & $(-)$ & & & $\Leftrightarrow$ & (土) \\
\hline 18 & 23 & 우 & " & 3 & $(+)$ & $(+)$ & & & $(-)$ & $( \pm)$ \\
\hline 19 & 24 & 우 & 11 & 6 & $(+)$ & $(+)$ & & & $(-)$ & (土) \\
\hline 20 & 23 & 우 & $"$ & 3.5 & $(+)$ & $(+)$ & & & $(-)$ & $(+)$ \\
\hline 21 & 25 & 우 & 看護婦 & 6.5 & $( \pm)$ & $(+)$ & & & $(-)$ & (土) \\
\hline 22 & 22 & 후 & i" & 11 & (I) & $( \pm)$ & & & $(-)$ & $( \pm)$ \\
\hline 23 & 17 & 우 & !l & 6.5 & $( \pm)$ & (士) & & & $(-)$ & $(+)$ \\
\hline 24 & 21 & 우 & $" \prime$ & 5.5 & $(-)$ & $(+)$ & & & $(-)$ & $(+)$ \\
\hline 25 & 19 & 우 & " & 5 & $(+)$ & $( \pm)$ & & & $(-)$ & $(+)$ \\
\hline 26 & 19 & 우 & $"$ & 4 & (土) & $( \pm)$ & & & $(-)$ & (士) \\
\hline 27 & 23 & 우 & " & 4.5 & $( \pm)$ & $( \pm)$ & & & $(-)$ & $( \pm)$ \\
\hline 28 & 18 & 우 &.$\prime \prime$ & 12 & $(+)$ & $(+)$ & & & $(-)$ & $(+)$ \\
\hline 29 & 17 & 우 & "I & 4 & $( \pm)$ & $( \pm)$ & & & $(-)$ & $(+)$ \\
\hline 30 & 21 & 우 & "I & 11 & $( \pm)$ & $( \pm)$ & & & $(-)$ & $(+)$ \\
\hline \multicolumn{3}{|c|}{ 男于本均 } & & 4.9 & $(+) \begin{array}{cc}1 & 2 \\
-+ & 6\end{array}$ & $\begin{array}{l}5 \\
6 \\
\end{array}$ & & & $\begin{array}{l}1 \\
0\end{array}$ & $\begin{array}{l}8 \\
0\end{array}$ \\
\hline \multicolumn{3}{|c|}{ 女子平均 } & & 6.4 & ( \pm$)^{\hat{a}}+12$ & $\begin{array}{l}6 \\
8 \\
\end{array}$ & & & $\begin{array}{l}2 \\
0\end{array}$ & $\begin{array}{r}14 ; \\
7\end{array}$ \\
\hline 總 & 45 & 均 & & 5.7 & $\left(-\begin{array}{cc}\hat{0} & 1 \\
0 & 1 \\
\end{array}\right.$ & $\begin{array}{l}4 \\
1 \\
\end{array}$ & & & $\begin{array}{l}12 \\
15 \\
\end{array}$ & $\begin{array}{l}1 \\
0 \\
\end{array}$ \\
\hline
\end{tabular}

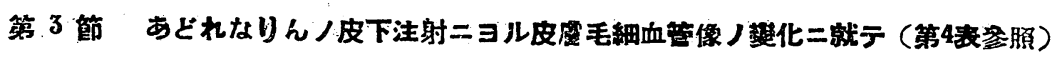

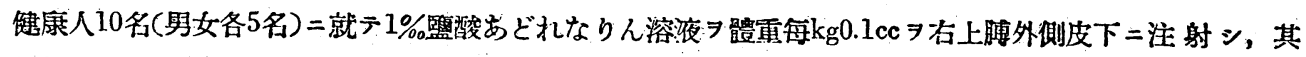

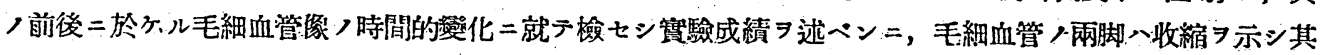

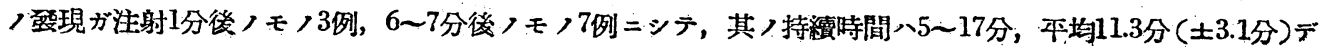


アル.

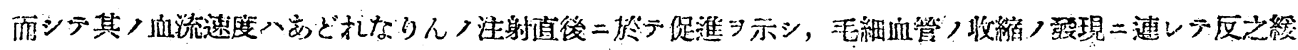

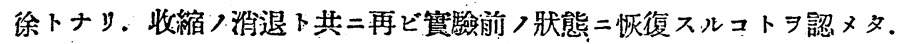

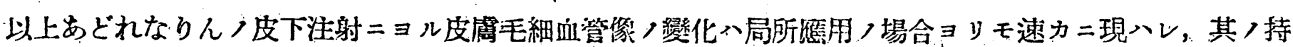
續時間ハ稍々長イント:タ認メタ.

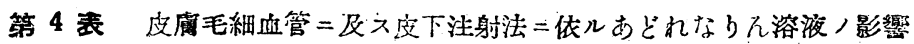

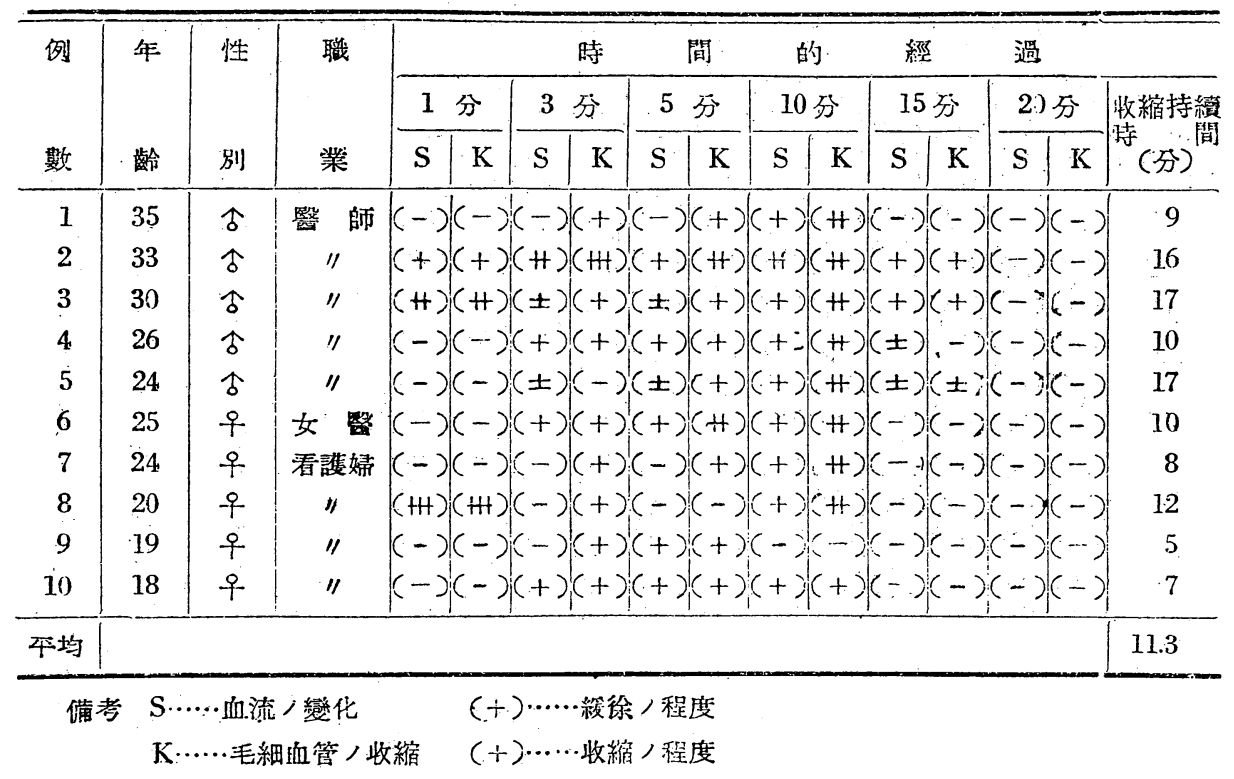

第 4 章、總括

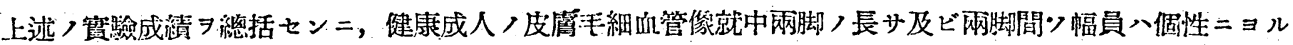
移動範園ガ稍々大 ガ認メ・ラレヌ。

血流速妵八略队一定ニシテ持續性 シシテ基底色調八淡赤色ノモノ過牛敖

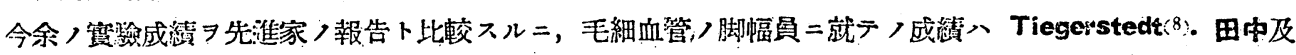

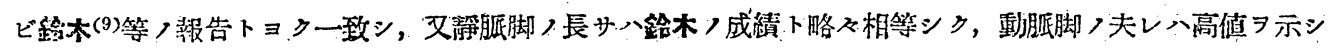
タ.

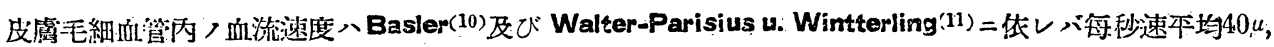

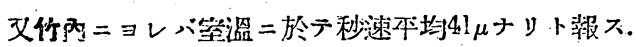

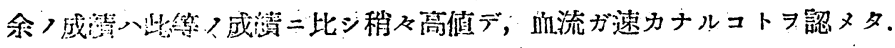

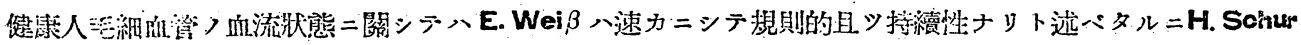

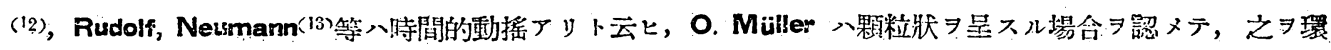

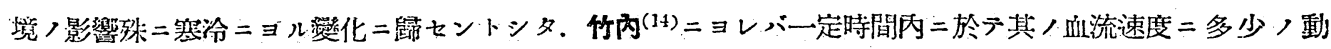

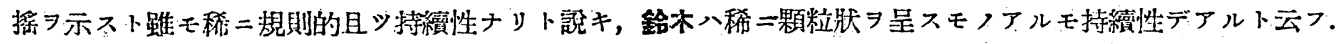

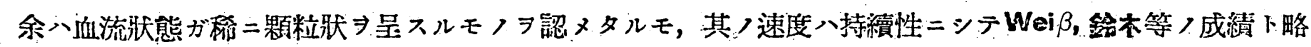
々相等シイ所㫕习铝メタ.

（2）2000倍まどれなりん・ぐりせりん溶液ノ局所反䳡ニョル皮膚毛細血管，反應時間》2 分 7 算シ，男 


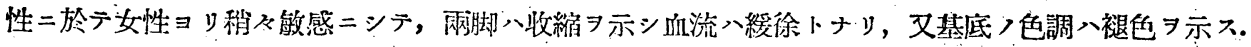

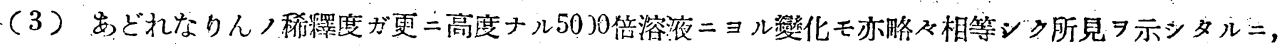

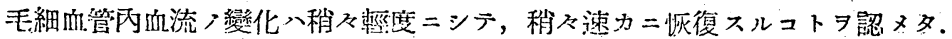

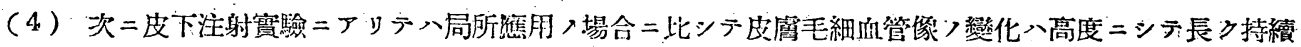

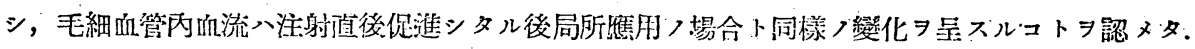

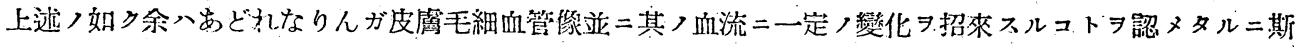

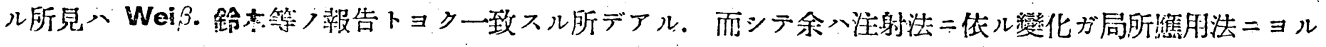

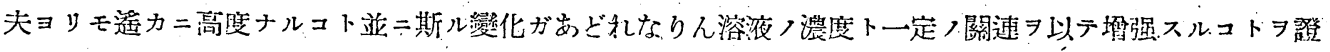

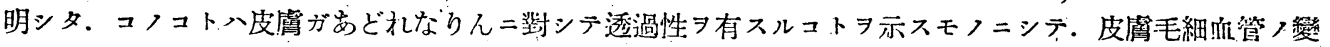
化八管二環境ノ影蠁ニヨルモノデナイコトヨ認メネバナラヌ。

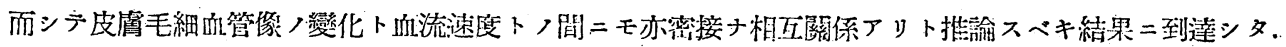

\section{第 5 蒘 結論}

以上ノ實驗成㵋 $\ni$ 要約スルト次, 如クデアル。

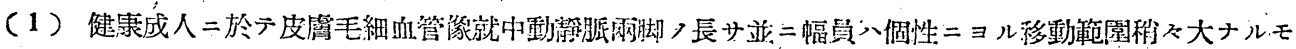

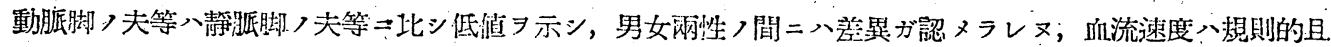

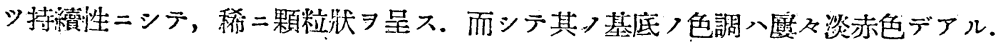

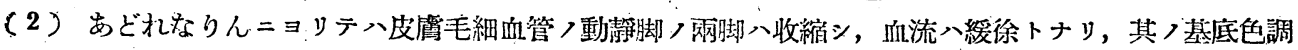

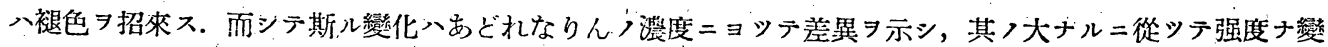
化ヨ示シ，局所應用二比シテ注射法二依儿變化ガ著シイコトラ認メタ.

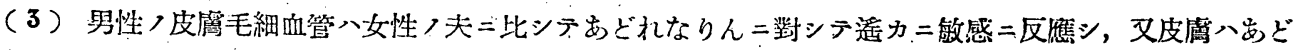
れなりんニ對ンテ透過性ヨ有スルコトラ認メタ.

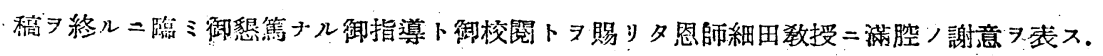

\section{主 裂 㣮}

1) Unna: Mh.Derm 12, 141(1891).

2) Lombard: Amer. J. Physiol 29, 335 (1912).

3) WNei $\beta$. EZ. exper. Path. u. Ther. 19, 390 (1918).

4. Mïller: Die Kapillaren d. Menschl: Körperoberzeche. 162.(1922).

5) Redisch. W.: Klin. Wschr 1924, 24.

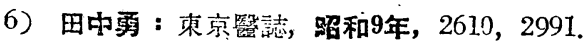

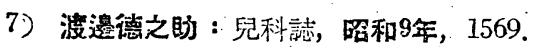

8) Tiegerssect, R: Zit. nach Müller. O. (4).

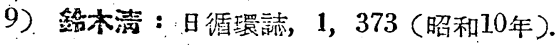

10) Basier A. Münch. Med. Wschr. 1919 (347).

11) Parisius. W. u. Wintterling: Dtsch. Arch. klin Med: 141, 243, (1923).

12) Sshur H: Wien Klin. Wschr. 1919 (1201).

13) Ruciols Neumam : Berl. Wschr 1920 (826).

14.) 竹內正明：京都管誌，28，200 (昭和6年). 